\title{
Systematic mutation analysis of KIAA0767 and KIAAI 646 in chromosome 22q-linked periodic catatonia
}

\author{
Gerald Stöber*1, Bernd Kohlmann ${ }^{1,2}$, Markus Siekiera ${ }^{1}$, Claudia Rubie ${ }^{1,3}$, \\ Micha Gawlik ${ }^{1}$, Kerstin Möller-Ehrlich ${ }^{1}$, Thomas Meitinger ${ }^{4}$ and \\ Thomas Bettecken ${ }^{4,5}$
}

Address: ${ }^{1}$ Department of Psychiatry and Psychotherapy, University of Würzburg, Füchsleinstraße 15, 97080 Würzburg, Germany, ${ }^{2}$ Department of Child and Youth Psychiatry and Psychotherapy, University of Würzburg, Füchsleinstraße 15, 97080 Würzburg, Germany, ${ }^{3}$ Department of General, Vascular and Paediatric Surgery, University of the Saarland, Homburg/Saar 66421, Germany, ${ }^{4}$ Institute of Human Genetics, Technical University of Munich \& GSF Ingolstädter Landstr. 1, 85764 Neuherberg, Germany and ${ }^{5}$ Max-Planck Institute of Psychiatry, Kraepelinstr. 2-10, 80804 Munich, Germany

Email: Gerald Stöber* - stoeber_g@klinik.uni-wuerzburg.de; Bernd Kohlmann - Kohlmann@kjp.uni-wuerzburg.de; Markus Siekiera - markus.sikiera@web.de; Claudia Rubie - ca.labor@uniklinikum-saarland.de; Micha Gawlik - gawlik_m@klinik.uniwuerzburg.de; Kerstin Möller-Ehrlich - Moeller_K1@klinik.uni-wuerzburg.de; Thomas Meitinger - meitinger@gsf.de; Thomas Bettecken - bettecken@mpipsykl.mpg.de

* Corresponding author

Published: 14 October 2005

BMC Psychiatry 2005, 5:36 doi:10.1186/147|-244X-5-36
Received: 09 June 2005

Accepted: 14 October 2005

This article is available from: http://www.biomedcentral.com/I47I-244X/5/36

(c) 2005 Stöber et al; licensee BioMed Central Ltd.

This is an Open Access article distributed under the terms of the Creative Commons Attribution License (http://creativecommons.org/licenses/by/2.0), which permits unrestricted use, distribution, and reproduction in any medium, provided the original work is properly cited.

\begin{abstract}
Background: Periodic catatonia is a familial subtype of schizophrenia characterized by hyperkinetic and akinetic episodes, followed by a catatonic residual syndrome. The phenotype has been evaluated in two independent genome-wide linkage scans with evidence for a major locus on chromosome $15 \mathrm{q} \mid 5$, and a second independent locus on chromosome $22 \mathrm{q}_{\mathrm{tel}}$.

Methods: In the positional and brain-expressed candidate genes KIAA0767 and KIAAI646, we searched for variants in the complete exons and adjacent splice-junctions as well as in parts of the 5 '- and 3'-untranslated regions by means of a systematic mutation screening in individuals from chromosome 22q-linked pedigrees.

Results: The mutation scan revealed 24 single nucleotide polymorphisms, among them two rare codon variants (KIAA0767: SI591; KIAAI646: V338G). However, both were neither found segregating with the disease in the respective pedigree nor found at a significant frequency in a casecontrol association sample.

Conclusion: Starting from linkage signals at chromosome22 $q_{\text {tel }}$ in periodic catatonia, we screened two positional brain-expressed candidate genes for genetic variation. Our study excludes genetic variations in the coding and putative promoter regions of KIAA0767 and KIAAI646 as causative factors for periodic catatonia.
\end{abstract}

\section{Background}

The phenotype of periodic catatonia is characterized by hyperkinetic and akinetic episodes with parakinetic movements in a bipolar course, accompanied by 
delusional or hallucinatory symptoms, and followed by residual states with psychomotor features $[1,2]$. The estimated lifetime prevalence of periodic catatonia is $\sim 0.001$ in the general population. Evidence for significant linkage to chromosome $15 \mathrm{q} 15$ was obtained and replicated in two independent genome-wide linkage scans $[3,4]$. Mainly supported by a single four-generation pedigree, a second locus was identified on chromosome $22 \mathrm{q}$ with a maximum multipoint LOD score of $2.59(\theta=0.0)$ under an autosomal dominant model at marker D22S1169, and with a heterogeneity $Z_{\max }$ of 1.57 with an estimated $38 \%$ of families linked [3]. Preliminary findings had suggested a link between MLC1 and catatonia via a putative dominantly acting missense mutation cosegregating in a large pedigree, but further analyses have excluded sequence variants of MLC1 as causing chromosome 22q-linked catatonia. MLC1 is the disease causing gene for autosomal recessively inherited megalencephalic leukoencephalopathy with subcortical cysts [5-7]. A systematic mutation screening in 140 index cases with periodic catatonia and five cases with MLC detected a high degree of sequence diversity of $M L C 1$ with evidence for further allelic heterogeneity of MLC1 mutations in MLC, but unfortunately the study failed to validate an association of schizophrenia to genetic variants of $M L C 1$. Among periodic catatonia index cases, the mutation scan revealed 15 different single nucleotide polymorphisms, among them three coding variants: two of them were observed in controls at a significant frequency, and the L309M variant, that was previously supposed to be the causative factor for chromosome $22 \mathrm{q}_{\text {tel }}$ linked periodic catatonia, was found non-segregating in a further multiplex pedigree [6]. In addition, MLC1 is a 377 amino acid protein with preferential expression in the brain and peripheral white blood cells. In the brain, MLC1 is specifically expressed in distal astroglial processes in perivascular, subependymal, and subpial regions. Although MLC1 shares low homology with human voltage-gated potassium channels, addressing the membrane topology and cellular localization of MLC1 supports the possible transport function of MLC1 for a specific, yet unknown substrate $[8,9]$. Thus, mutations in $M L C 1$ are causative for MLC, but can be excluded as a susceptibility factor in schizophrenia. Reports of other groups also failed to support an aetiological relevance of this gene in schizophrenia [10-12] and more importantly, these studies $[6,12]$ rule out that spongiform leukodystrophies and subtypes of schizophrenia are allelic disorders.

Under the assumption of disease heterogeneity and allelic heterogeneity [13], we screened in a systematic approach the positional candidate genes KIAA1646 and KIAA0767, located between 45.34-45.45 Mb [14], for genetic variation. Human KIAA0767 is a mitochondrial protein of 578 amino acids (aa) with high expression in adult brain and strong pro-apoptotic effect $[15,16]$. KIAA1646 is a cyto- plasmatic and membrane-associated ceramide kinase (CERK) of 537 amino acids [17]. CERK is acting in the signal transduction cascade and is suggested to be involved in the process of synaptic vehicle fusion [18]. KIAA0767 and KIAA1646 consist of 18 and 13 exons, respectively, spanning each $\sim 50 \mathrm{~kb}$ on genomic DNA.

\section{Methods}

We selected two affected individuals $(933,1045)$ from different branches of F20, and two cases $(727,857)$ of smaller pedigrees F15 and F17, which were compatible with linkage to chromosome 22q [19], as well as DNA of a healthy individual as control. In the association study we included 115 unrelated cases with periodic catatonia (66 males; mean age first hospitalisation: 26.2 years, SD 10.5; age at assessment: 44.6 years, SD 17.1) and 110 blood donors as controls (60 males; mean age at assessment: 29.5 years, SD 9.4). All subjects actively participated in the study after giving informed consent. The Ethics Committee of the University of Würzburg had approved the study.

Primers covered in overlapping fragments parts of the 5'UTR containing putative promoter regions [20] and were allocated in intronic regions to encompass the complete exon and adjacent splice-junctions as well as parts of the $3^{\prime}$-UTR up to $\sim 1.0 \mathrm{~kb}$. PCR $\left(30 \mathrm{sec}\right.$ at $94^{\circ} \mathrm{C}, 30 \mathrm{sec}$ at $57^{\circ} \%$ $60^{\circ} \mathrm{C}$, and $30 \mathrm{sec}$ at $72^{\circ} \mathrm{C}$ for 32 cycles) was carried out in $25 \mu \mathrm{l}$ reaction volumes containing $\sim 80 \mathrm{ng}$ genomic DNA, $20 \mathrm{pmol}$ of each primer, $200 \mu \mathrm{M}$ of each dNTP, $0.5 \mathrm{U}$ Taq DNA polymerase (Fermentas), and buffer as supplied by the manufacturer in a MJ Research 96-well block Tetrad thermocycler (Waltham, MA). Exon 1 of CERK was not sequenced because of technical difficulties. PCR products were purified by solid phase extraction and bidirectionally sequenced with ABI PRISM 3100 Genetic Analyzer (Applied Biosystems, Foster City, CA, USA) followed by computer-assisted analyses. For restriction fragment analyses (RFLP) PCR products were amplified on a Thermocycler (Biometra, Göttingen), and subsequently digested with the appropriate enzyme (CERK V338G: DraIII; KIAA0767 S159I: MboI). Fragments were resolved on a $10 \%$ PAA gel containing $1.0 \times \mathrm{TBE}$ at $15 \mathrm{~V} / \mathrm{cm}^{2}$ followed by silverstaining.

\section{Results}

In the mutation screening sample we identified seven single nucleotide polymorphisms (SNPs) at the KIAA0767/ DIP locus (Table 1). Nt $45379466 \mathrm{G}>\mathrm{T}$ changes a serine to isoleucine (S159I). We identified case 857 as a heterozygote carrier; the variant, however, did not co-segregate with the disease in the multiplex pedigree. The SNP was introduced through an unaffected individual, who married into the family. In addition, we did not observe 159I in a sample of 450 chromosomes (115 index cases with 
Table I: sequence variable at the KIAA0767/DIP locus on chromosome 22q13. 3

\begin{tabular}{|c|c|c|c|c|c|c|c|c|c|c|}
\hline \multirow[t]{2}{*}{ Nucleotide position * } & \multirow[t]{2}{*}{ DNA level } & \multirow[t]{2}{*}{ Nucleotide change } & \multirow[t]{2}{*}{ Codon } & \multirow[t]{2}{*}{ SNP-database } & \multicolumn{6}{|c|}{ Genotypes of the individuals from each family } \\
\hline & & & & & 933 & 1045 & 727 & 857 & Ctrl & Allele frequency \\
\hline 45377716 & Intron 3 & $C>T$ & - & rs 2076708 & $\mathrm{CC}$ & $\mathrm{CC}$ & $\mathrm{CC}$ & $\mathrm{CC}$ & $\mathrm{CT}$ & C: $0.9 \mathrm{~T}: 0.1$ \\
\hline 45379466 & Exon 5 & $G>T$ & SI59I & - & GG & GG & GG & GT & GG & G: $0.9 \mathrm{~T}: 0.1$ \\
\hline 45385184 & Intron II & $\mathrm{C}>\mathrm{T}$ & - & - & CT & $\mathrm{CC}$ & $\mathrm{CC}$ & $\mathrm{CC}$ & $\mathrm{CT}$ & C: $0.8 \mathrm{~T}: 0.2$ \\
\hline 45385356 & Intron 12 & $A>C$ & - & rs 20767III & AA & AA & AA & AA & $A C$ & A: 0.9 C: 0.1 \\
\hline 45391987 & Intron 16 & $\mathrm{C}>\mathrm{T}$ & - & - & $\mathrm{CC}$ & $\mathrm{CC}$ & $\mathrm{CC}$ & $\mathrm{CC}$ & $\mathrm{CT}$ & C: $0.9 \mathrm{~T}: 0 . \mathrm{I}$ \\
\hline 45392051 & Intron 16 & $\mathrm{~T}>\mathrm{C}$ & - & - & TT & TT & $\mathrm{TC}$ & $\mathrm{TC}$ & $\mathrm{TC}$ & $\mathrm{T}: 0.7 \mathrm{C}: 0.3$ \\
\hline 45392996 & Intron 16 & $G>A$ & - & rs 2236028 & GA & GG & GG & GG & GA & G: $0.8 \mathrm{~A}: 0.2$ \\
\hline
\end{tabular}

* nt position according the UCSC Genome Browser May 2004 assembly [I4; NMI_022766].

Nucleotide changes found by automated sequencing of amplicons of four individuals from pedigrees segregating periodic catatonia evaluated in a genome-wide linkage scan [3, 19]: 933 and 1045 (F20), 727 and 857 (FI5,FI7), and a control subject.

periodic catatonia and 110 controls, respectively). These findings coincidently indicated that 159 I is a rare variant, but not associated with disease susceptibility.

The systematic scan of KIAA1646/CERK resulted in a total of 17 SNPs (Table 2). We observed the coding variant 338G by sequencing DNA-amplicons of a control subject. In a subsequent case-control association study, we found a frequency of the heterozygous genotype of $0.9 \%$ ( 2 out of 220 alleles) compared to a frequency of the heterozygous genotype of $2.2 \%$ in periodic catatonia (5 out of 230 alleles; ns). In addition, the variants C50 and D377 were both non-segregating within the multiplex pedigree F20, as did the synonymous N500 in the respective pedigrees.

Eleven of the 24 SNPs had not yet been deposited in current databases. At the CERK locus rs 2542014 was linked to a nearby $(+2 \mathrm{bp})$ variant at nt 45403531 . The intronic SNPs at nt 45415691C>G (KIAA1646) and nt 45392050 T>C (KIAA0767) were found at allelic frequencies useful for further LD-mapping studies.

\section{Discussion}

Sustained interest in schizophrenia susceptibility on chromosome $22 \mathrm{q}$ is substantiated by several genome-wide linkage studies on schizophrenic psychoses [21-23]. Because of reports of schizophrenia susceptibility genes within the 22q11 region, this locus has obtained a high marker density compared to the 22q13 region [24]. Although only weak signals for linkage to chromosome $22 \mathrm{q} 11$ were received by recent multicenter and meta-analytic studies $[25,26]$, subsets of pedigrees in the study by Mowry et al. [25] gave positive scores for chromosome $22 \mathrm{q} 13$, particularly if accounting for intersample heterogeneity. The pedigrees analyzed here were not part of these multicenter samples. We focused on the phenotype periodic catatonia [[27]; \#605419] with a major disease locus at chromosome $15 \mathrm{q} 15$, and at least one further independent locus at chromosome 22q13, mainly supported by a large four-generational pedigree [3]. As it has been already demonstrated in several chromosome $15 \mathrm{q} 15$-linked pedigrees, haplotype analyses in pedigree F20 showed autosomal dominant transmission $[3,6]$. The lack of common haplotypes in unrelated families, however, added further evidence to genetic and allelic heterogeneity in periodic catatonia.

The chromosome $22 \mathrm{q}_{\mathrm{tel}}$ candidate locus of $\sim 4 \mathrm{Mb}$ comprises more than 45 genes [28], and harbours several genes involved in severe neuropsychiatric disorders, such as metachromatic leukodystrophy and megalencephalic leukoencephalopathy [[27]: \#250100; \#604004]. In a systematic mutation scan of positional candidates at the chromosome $22 q_{\text {tel }}$ candidate region we screened $~ 3400$ nt of coding sequence including splice-donor sites and additionally parts of the 5'-UTR and 3'-UTR of KIAA0767 and KIAA1646, respectively. The mutation scan revealed 24 sequence variants, among them two rare codon variants (KIAA0767: S159I; KIAA1646: V338G). However, both neither were found to segregate with the disease in the respective pedigrees nor found at a significant frequency in periodic catatonia.

Human KIAA0767/DIP [GenBank: NM 015124; LocusLink: 23151] consists of 18 exons, spanning $\sim 50 \mathrm{~kb}$ on genomic DNA [NT_011523.2]. KIAA0767 is a protein of 578 amino acids (aa) putatively localized in the mitochondrion [16]. KIAA0767 expression resulted in a significant loss of cell viability independent of the p53 status, and thus, termed death-inducing-protein (DIP) because of its strong pro-apoptotic effect [16]. DIP shows at least two transmembrane domains and multiple putative phosphorylation and glycolisation sites. The variant S159I, 
Table 2: Polymorphisms at the KIAA 1646/CERK locus in periodic catatonia

\begin{tabular}{|c|c|c|c|c|c|c|c|c|c|c|}
\hline \multirow[t]{2}{*}{ Nucleotide position* } & \multirow[t]{2}{*}{ DNA level } & \multirow[t]{2}{*}{ Nucleotide change } & \multirow[t]{2}{*}{ Codon } & \multirow[t]{2}{*}{ SNP-database } & \multicolumn{6}{|c|}{ Genotypes of the individuals from each family } \\
\hline & & & & & 933 & 1045 & 727 & 857 & Ctrl & Allele frequency \\
\hline 45437424 & Exon 2 & $G>A$ & $\mathrm{C} 50$ & rs 12166204 & GG & GA & GG & GG & GG & G: $0.9 ; A: 0.1$ \\
\hline 45418024 & Intron 7 & $\mathrm{C}>\mathrm{T}$ & - & rs 16995595 & GT & $\mathrm{CC}$ & $\mathrm{CC}$ & $\mathrm{CC}$ & $\mathrm{CC}$ & C: $0.9 ; \mathrm{T}: 0.1$ \\
\hline 45415928 & Intron 7 & $C>G$ & - & - & CG & GG & CG & $\mathrm{CC}$ & CG & C: $0.5 ; \mathrm{G}: 0.5$ \\
\hline $454|569|$ & Intron 8 & $C>G$ & - & rs 5767329 & $\mathrm{CC}$ & $\mathrm{CC}$ & CG & CG & $\mathrm{CC}$ & C: $0.8 ; \mathrm{G}: 0.2$ \\
\hline 45411750 & Intron 8 & $G>A$ & - & rs 9616098 & GG & GG & GG & GG & GA & G: $0.9 ; A: 0.1$ \\
\hline 45411662 & Exon 9 & $A>C$ & V338G & - & $A A$ & $A A$ & AA & $A A$ & $A C$ & A: $0.9 ; C: 0.1$ \\
\hline 45409793 & Intron 10 & $G>A$ & - & - & GG & GG & GA & GA & GG & G: $0.8 ; A: 0.2$ \\
\hline 45408189 & Exon II & $G>A$ & D377 & - & GA & GG & GG & GG & GA & G: $0.8 ; A: 0.2$ \\
\hline 45406443 & Exon 12 & $G>A$ & D502 & - & GG & GG & GA & GA & GG & G: $0.8 ; A: 0.2$ \\
\hline 45403531 & 3'- UTR & $\mathrm{T}>\mathrm{A}$ & - & - & TA & TT & TA & TA & AA & $\mathrm{T}: 0.5 ; \mathrm{A}: 0.5$ \\
\hline 45403529 & 3'-UTR & $\mathrm{T}>\mathrm{C}$ & - & rs 2542014 & $\mathrm{TC}$ & TT & TC & $\mathrm{TC}$ & $\mathrm{CC}$ & $\mathrm{T}: 0.5 ; \mathrm{C}: 0.5$ \\
\hline 45403096 & 3'-UTR & $G>T$ & - & rs 8143065 & GG & GG & GT & GT & GG & G: $0.8 ; \mathrm{T}: 0.2$ \\
\hline 45402864 & 3'-UTR & $C>T$ & - & rs 801719 & $\mathrm{CC}$ & $\mathrm{CC}$ & $\mathrm{CT}$ & $\mathrm{CT}$ & $\mathrm{CT}$ & C: $0.7 ; \mathrm{T}: 0.3$ \\
\hline 45402678 & 3'-UTR & $C>A$ & - & rs 801720 & $\mathrm{CC}$ & $\mathrm{CC}$ & $C A$ & CA & AA & C: $0.6 ; A: 0.4$ \\
\hline 45402542 & 3'-UTR & $G>A$ & - & rs 3747258 & GG & GG & GA & GA & GG & G: $0.8 ; A: 0.2$ \\
\hline 45402502 & 3'-UTR & $C>T$ & - & - & $\mathrm{CC}$ & $\mathrm{CC}$ & $\mathrm{CT}$ & $\mathrm{CT}$ & $\mathrm{CC}$ & $C: 0.8 ; T: 0.2$ \\
\hline 45402374 & 3'-UTR & $A>G$ & - & rs 2748348 & $A A$ & $A A$ & $A G$ & $A G$ & AA & A: $0.8 ; \mathrm{G}: 0.2$ \\
\hline
\end{tabular}

* nt position according the UCSC Genome Browser May 2004 assembly [14; NMI_022766].

however, seems not to affect any of the various functional DIP/KIAA0767 protein domains.

Human KIAA1646/CERK [GenBank: NM 022766; LocusLink: 64781] consists of 13 exons, spanning $\sim 50 \mathrm{~kb}$ on genomic DNA. CERK is a cytoplasmatic and membrane-associated protein of 537 amino acids with a calculated molecular weight of $60 \mathrm{kDa}$. It is a member of a new class of lipid kinases and acts in the signal transduction cascade of the control of apoptosis catalyzing specifically the phosphorylation of ceramide [17]. The component ceramide is thought to regulate apoptotic responses to stress, particularly those initiated by the mitochondria. CERK is highly expressed in brain and leukocytes, and is suggested to be involved in synaptic neurotransmitter release [18] or in phagocytosis and vehicle fusion in neutrophils and mast cells $[17,29,30]$. In CERK, the pleckstrin homology domain and the diacylglycerol kinase (DGK) catalytic domain were found non-polymorphic, but V338G was located in the central homologous region, near the casein kinase II phosphorylation site at S340, and V338 is conserved between human and mouse CERK $[17,31]$. Although V338G may be of functional relevance, it was not found associated with periodic catatonia. Recent reports that mutations in the related gene CERKL on chromosome 2q31 cause autosomal recessive retinitis pigmentosa (RP26) indicate a link of the ceramide kinase gene family to retinal neurodegeneration [32].
Starting from linkage signals at chromosome $22 \mathrm{q}_{\mathrm{tel}}$ in periodic catatonia, we screened two positional brainexpressed candidate genes for genetic variation (KIAA0767/DIP; KIAA1646/CERK). Our study excludes variants at coding and putative promoter regions as causative factors in periodic catatonia, but do not exclude the involvement of other regulatory elements in intronic or extended promoter regions. Although negative, the present study narrowed down the putative susceptibility region, and provides a systematic SNP generation for forthcoming LD studies.

\section{Competing interests}

The author(s) declare that they have no competing interests.

\section{Authors' contributions}

BK, MS, CR performed laboratory assays, MG, KME performed the data-analysis and drafted the manuscript, TM, TB participated in the design of the study and its coordination, GS participated in the design of the study, interpretation of the data, and drafting of the manuscript. All authors read and approved the final manuscript.

\section{Acknowledgements}

This work was supported by the Deutsche Forschungsgemeinschaft.

\section{References}

I. Leonhard K: Classification of endogenous psychoses and their differentiated etiology 2nd rev. and enlarged edition. Wien, New York: Springer; 1999: I04-II2. 30I-308 
2. Stöber G: Genetics. In Catatonia. From psychopathoplogy to neurobiology Edited by: Caroff SN, Mann SC, Francis A, Fricchione GL. Washington DC, London: American Psychiatric Press; 2004: 173-187.

3. Stöber G, Saar K, Rüschendorf F, Meyer J, Nürnberg G, Jatzke S, Franzek E, Reis A, Lesch KP, Wienker TF, Beckmann H: Splitting schizophrenia: periodic catatonia-susceptibility locus on chromosome I5q I5. Am J Hum Genet 2000, 67:I20I-I207.

4. Stöber G, Seelow D, Rüschendorf F, Ekici A, Beckmann H, Reis A Periodic catatonia: confirmation of linkage to chromosome 15 and further evidence for genetic heterogeneity. Hum Genet 2002, I I I:323-330.

5. Leegwater PAJ, Yuan BO, van der Stehen J, Mulders J, Könst AAM, Boor PKI, Mejaski-Bosnjak V, van der Maarel SM, Frants RR, Oudejans CBM, Schutgens RBH, Pronk JC, van der Knaap MS: Mutations of MLCI (KIAA0027), encoding a putative membrane protein, cause megalencephalic leucoencephalopathy with subcortical cysts. Am J Hum Genet 200I, 68:83 I-838.

6. Rubie C, Lichtner P, Gärtner J, Siekiera M, Uzig G, Kohlmann B, Kohlschütter A, Strom T, Meitinger T, Stöber G, Bettecken T: Sequence diversity of KIAA0027/MLCI: are megalencephalic leukoencephalopathy and schizophrenia allelic disorders? Hum Mutat 2003, $21: 45-52$.

7. Meyer J Huberth A Ortega G, Syagailo YV, Jatzke S, Mössner R, Strom T, Ulzheimer-Teuber I, Stöber G, Schmitt A, Lesch KP: A missense mutation in a novel gene encoding a putative cation channel is associated with catatonic schizophrenia in a large pedigree. Mol Psychiatry 200I, 6:304-308.

8. Kaganovich M, Peretz A, Ritsner M, Bening Abu-Shach U, Attali B, Navon R: Is the WKLI gene associated with schizophrenia? Am J Med Genet Neuropsychiatr Genet 2004, I 25:3 I-37.

9. Boor PK, de Groot K, Waisfisz Q, Kamphorst W, Oudejans CB, Powers JM, Pronk JC, Scheper GC, van der Knaap MS: MLCI: a nove protein in distal astroglial processes. J Neuropathol Exp Neurol 2005, 64:4I2-4I9.

10. Devaney JM, Donarum EA, Brown KM, Meyer J, Stöber G, Lesch KP, Nestadt G, Stephan DA, Pulver AE: No missense mutation of WKLI in a subgroup of probands with schizophrenia. Mol Psychiatry 2002, 7:419-423.

II. McQuillin A, Kalsi G, Moorey H, Lamb G, Mayet S, Quested D, Baker $P$, Curtis D, Gurling HM: A novel polymorphism in exon II of the WKLI gene, shows no association with schizophrenia. Eur J Hum Genet 2002, 10:49I-494.

12. Leegwater PA, Boor PK, Pronk JC, van der Knaap MS: Association of WKLI/MLCI with catatonic schizophrenia. Mol Psychiatry 2002, 7:1037.

13. Pritchard JK, Cox NJ: The allelic architecture of human disease genes: common disease-common variant...or not? Hum Mol Genet 2002, I I:2417-2423.

14. [http://www.genome.ucsc.edu/]

15. Kikuno R, Nagase T, Nakayama M, Koga H, Okazaki N, Nakajima D, Ohara O: HUGE: a database for human KIAA proteins, a 2004 update integrating HUGEppi and ROUGE. Nucleic Acids Res 2004, 32:502-504.

16. Stanelle J, Tu-Rapp H, Pützer BM: A novel mitochondrial protein DIP mediates E2FI-induced apoptosis independently of $\mathrm{p} 53$ Cell Death Differ 2005, 1 2:347-357.

17. Sugiura M, Kono K, Liu H, Shimizugawa T, Minekura H, Spiegel S, Kohama T: Ceramide kinase, a novel lipid kinase. Molecular cloning and functional characterization. I Biol Chem 2002, 277:23294-23300

18. Bajialieh SM, Martin TFJ, Floor E: A synaptic vesicle ceramide kinase. A calcium-stimulated lipid kinase that co-purifies with brain synaptic vesicles. J Biol Chem 1989, 264: I4354-I4360.

19. Stöber G, Pfuhlmann B, Nürnberg G, Schmidtke A, Reis A, Franzek E, Wienker TF: Towards the genetic basis of periodic catatonia: pedigree sample for genome scan I and II. Eur Arch Psychiatry Clin Neurosci 200I, 25 I (SuppI I):25-30.

20. [http://thr.cit.nih.gov/].

21. Coon HS, Jensen M, Holik J, Hoff M, Myles-Worsley M, Reimherr F, Wender P, Leppert M, Byerley W: Genomic scan for genes predisposing to schizophrenia. Am J Med Genet 1994, 54:59-7I.

22. Blouin JL, Dombroski BA, Nath SK, Lasseter VK, Wolyniec PS, Nestadt G, Thornquist M, Ullrich G, McGrath J, Kasch L, Lamacz M, Thomas MG, Gehrig C, Radhakrishna U, Snyder SE, Balk KG, Neufeld K, Swartz KL, DeMarchi N, Papadimitriou GN, Dikeos DG, Stefanis CN, Chakravarti A, Childs B, Housman DE, Kazazian $\mathrm{HH}$, Antonarakis S,
Pulver AE: Schizophrenia susceptibility loci on chromosomes 13q32 and 8p21. Nat Genet 1998, 20:70-73.

23. DeLisi LE, Shaw SH, Crow TJ, Shields G, Smith AB, Larach VW, Wellman N, Loftus J, Nanthakumar B, Razi K, Stewart J, Comazzi M, Vita A, Heffner T, Sherrington R: A genome-wide scan for linkage to chromosomal regions in $\mathbf{3 8 2}$ sibling pairs with schizophrenia or schizoaffective disorder. Am J Psychiatry 2002, | 59:803-8| 2.

24. Harrison PJ, Owen MJ: Genes for schizophrenia? Recent findings and their pathophysiological implications. Lancet 2003 , 361:417-419.

25. Mowry BJ, Holmans PA, Pulver AE, Gejman PV, Riley B, Williams NM, Laurent C, Schwab SG, Wildenauer DB, Bauche S, Owen MJ, Wormley B, Sanders AR, Nestadt G, Liang KY, Duan J, Ribble R, Norton N, Soubigou S, Maier W, Ewen-White KR, DeMarchi N, Carpenter B, Walsh D, Williams H, Jay M, Albus M, Nertney DA, Papadimitriou G, O'Neill A, O'Donovan MC, Deleuze JF, Lerer FB, Dikeos D, Kendler KS, Mallet J, Silverman JM, Crowe RR, Levinson DF: Multicenter linkage study of schizophrenia loci on chromosome 22q. Mol Psychiatry 2004, 9:784-795.

26. Lewis CM, Levinson DF, Wise LH, DeLisi LE, Straub RE, Hovatta I, Williams NM, Schwab SG, Pulver AE, Faraone SV, Brzustowicz LM, Kaufmann CA, Garver DL, Gurling HM, Lindholm E, Coon H, Moises HW, Byerley W, Shaw SH, Mesen A, Sherrington R, O'Neill FA, Walsh D, Kendler KS, Ekelund J, Paunio T, Lonnqvist J, Peltonen L, O'Donovan MC, Owen MJ, Wildenauer DB, Maier W, Nestadt G, Blouin JL, Antonarakis SE, Mowry BJ, Silverman JM, Crowe RR, Cloninger CR, Tsuang MT, Malaspina D, Harkavy-Friedman JM, Svrakic DM, Bassett AS, Holcomb J, Kalsi G, McQuillin A, Brynjolfson J, Sigmundsson T, Petursson H, Jazin E, Zoega T, Helgason T: Genome scan meta-analysis of schizophrenia and bipolar disorder, part II: Schizophrenia. Am / Hum Genet 2003, 73:34-48.

27. Online Mendelian Inheritance in Man (OMIM) [http:// www.ncbi.nlm.nih.gov/]

28. [http://www.sanger.ac.uk/HGP/Genes/]

29. Hinkovska-Galcheva V, Kjeldsen L, Mansfield PJ, Boxer LA, Shayman JA, Suchard SJ: Activation of a plasma membrane-associated neutral sphingomyelinase and concomitant ceramide accumulation during IgG-dependent phagocytosis in human polymorphonuclear leukocytes. Blood 1998, 9 I:476I-4769.

30. Mitsutake S, Kim T], Inagaki Y, Kato M, Yamashita T, Igarashi Y: Ceramide kinase is a mediator of calcium-dependent degranulation in mast cells. J Biol Chem 2004, 279: 17570-I7577.

31. Bornancin F, Mechtcheriakova D, Stora S, Graf C, Wlachos A, Devay P, Urtz N, Baumruker T, Billich A: Characterization of a ceramide kinase-like protein. Biochim Biophys Acta 2005, 1687:31-43.

32. Tuson M, Marfany G, Gonzalez-Duarte R: Mutation of CERKL, a novel human ceramide kinase gene, causes autosomal recessive retinitis pigmentosa (RP26). Am J Hum Genet 2004, 74: $128-138$

\section{Pre-publication history}

The pre-publication history for this paper can be accessed here:

\section{http://www.biomedcentral.com/1471-244X/5/36/pre} pub

Publish with Bio Med Central and every scientist can read your work free of charge

"BioMed Central will be the most significant development for disseminating the results of biomedical research in our lifetime. "

Sir Paul Nurse, Cancer Research UK

Your research papers will be:

- available free of charge to the entire biomedical community

- peer reviewed and published immediately upon acceptance

- cited in PubMed and archived on PubMed Central

- yours - you keep the copyright
BioMedcentral 